\title{
Safety and Hazards in Petroleum Industries: Research, Studies and Surveys
}

\author{
Sunil Jayant Kulkarni \\ Datta Meghe College of Engineering, Airoli, Navi Mumbai, \\ Maharashtra, India
}

\begin{abstract}
Environmental friendly and safe operations and processes are always desired from health perspectives. Due to properties of chemicals in petroleum sector, the chances of accidents are high. Material, substances, processes or circumstances which pose threat to health and well being of workers in any occupation are termed as occupational hazards. The health and safety of worker is most important. Operations and processes in petroleum industries are hazardous, due to properties of the petroleum products and raw materials. Various investigations and studies are reported on the safety and hazards in petroleum and refining industries. It is necessary to identify occupational health hazard in addition to occupational safety hazard.
\end{abstract}

Keywords: Hazards, awareness level, industry workers, risk assessment, exposure.

\section{INTRODUCTION}

In today's world, energy requirement defines growth of the nation. It is key to industrial development. Petroleum and petrochemical sectors are back bone of economical growth. The cost of fuel, many times determines cost of commodities. Many unconventional energy resources are being explored with more or less success $[1,2,3,4]$. Production of ethanol from different feed stocks is being explored $[5,6,7]$. Still there is large dependence on fossil fuel. Oil exploration remains most important activity towards energy demand fulfillment. The research and studies are being carried out to make the activities in these industries environmental friendly. Petroleum and refining sector is experiencing many challenges. The treatment of flue gases for removal of harmful gases is one such aspect of these investigations $[8,9,10,11,12]$. Also wastewater treatment for these plants is being dealt with best possible technology and many investigations are reported on the same [13,14,15]. Sludge and solid waste treatment is also important area of research $[16,17,18]$. The removal of impurities from crude and product constitutes upstream and downstream processing in petroleum sector. Environmental friendly and safe operations and processes are always desired from health perspectives. Due to properties of chemicals in petroleum sector, the chances of accidents are high. Material substances, processes or circumstances which pose threat to health and well being of workers in any occupation are termed as occupational hazards $[19,20]$.The health and safety of worker is most important. Various investigations and studies are reported on the safety and hazards in petroleum and refining industries. Current review summarizes research and studies on safety and hazards in petroleum industries.

\section{SAFety ANd Hazards in Petroleum Industries: Research, Studies ANd Surveys}

Uehara, in his lecture, discussed fire safety assessments in petrochemical plants [21]. He presented two safety assessment methods. Aliyu and Saidu assessed the pattern of occupational hazards [22].In their work, they surveyed provision of occupational health service and safety measures among workers. They found that the awareness level of hazards was satisfactory. They also found that 44 percent respondents had injury in the course of their work. Salter from Shell Global Solutions presented a report on safety at the seventh world congress of chemical engineers Glasgow, Scotland [23]. Eyayo investigated occupational health hazards among oil industry workers [24]. He carried out case study on refinery workers. According to him, it is imperative that one should identify occupational health hazard in addition to occupational safety hazard. He listed these hazards as physical health hazard, chemical health hazard, biological health hazard, mechanical/ergonomic health hazard and psychosocial health hazard. The opinion of workers indicated that management was committed to the 
health and well-being of their workers. He recommended health effect management process as an element in occupational health and safety management system (OHS-MS) amongst others. It was recommended management protocol that would assist the management of an oil and gas refinery. Edokpolo et.al. carried out health risk assessment for exposure to benzene in petroleum refinery environments[25]. They calculated the health risk resulting from benzene exposure in petroleum refineries with the help from the scientific literature from various countries throughout the world. They prepared cumulative probability distributions (CPD) plots. For this they collated the exposure data into four scenarios from petroleum refinery environments. They used slope factor and overall risk probability (ORP) methods for evaluation of the excess cancer risk (CR) for lifetime exposure to benzene. Ezejiofor et.al. Carried out risk assessment studies on re-appraisals for potential hazards in the operational environment and facilities[26].The objective of their studies was appraisal of potential hazards in the operational environment and facilities. Their study involved participation in the activities of the various units. Careful study of few establishments revealed that many have become obsolete, defective and hazardous. They also found that major hazards include physical, chemical, biological, psychosocial and ergonomic hazards. According to them, various job exposures are responsible for the accidents, injuries, morbidities and mortalities. In the conclusion, they expressed need for facility upgrade and industrial health Services updates. According to Islam, oily sludges are hazardous wastes as found in environment protection act and hazardous wastes handling rules [27]. They found that, during oil processing, the sludge accumulate in crude oil tanks, refinery products tanks, desalters, and elsewhere. According to them, it is necessary to make the sludge harmless before disposal. In his work, Khan presented risk assessment in petroleum industries [28]. According to him, operations and processes in petroleum industries are hazardous, due to properties of the petroleum products and raw materials. These materials and compounds are volatile, flammable and inflammatory. They emphasized that, it is important to understand the properties, energy associated with compounds and thermal stability. According to Witter et.al., the occupational hazard is major issue in oil and gas extraction industry [29]. According to their study, fatality rate in this industry is 2.5 times more than construction industry and 7 times more than general industry. According to them, it is necessary to have collaborative approach between educational firms and industries. This approach can help in identification of actual root cause of accidents and fatalities. Also it can help in assessment of mitigation efficacy programs. According to Bachmann et.al.it is important from safety perspectives that, one should remove sulfur, metal, nitrogen as well as undesirable organic compounds from the crude [30]. According to them, most of the inorganic impurities are removed by chemical and physical refinery processes such as hydrodesulfurization, desalting, and high-pressure high-temperature hydrotreating.

\section{CONClusion}

Material substances, processes or circumstances which pose threat to health and well being of workers in any occupation are termed as occupational hazards. The health and safety of workers is most important. Operations and processes in petroleum industries are hazardous, due to properties of the petroleum products and raw materials. the occupational and hazard is major issue in oil and gas extraction industry . According to studies by an investigator, fatality rate in this industry is 2.5 times more than construction industry and 7 times more than general industry. One should remove sulfur, metal, nitrogen as well as undesirable organic compounds from the crude.

\section{REFERENCES}

[1] Toshi H. Arimura Kazuyuki Iwata, 2010, "Measures to Protect the Environment and Conserve Energy Taken by the United States and Japan: Review of Quantitative Analysis", Far eastern studies, 9, PP.65-87.

[2] Sunill J. Kulkarni, 2015, "Tidal Energy: A Review", International Journal of Research, 2(1), PP.55-58.

[3] Patil V.S. and Deshmukh H.V., 2015, "Anaerobic Digestion of Vegetable Waste for Biogas generation: A Review", International Research Journal of Environment Sciences, 4(6), PP.80-83.

[4] Sunil J. Kulkarni, 2014, "Solar Distillation: A Review", International Journal of Research, 1(11), PP.1171-1176.

[5] Stephanie Lee Groves, 2009, "Optimization of ethanol production by yeasts from lignocellulosic feedstocks", Dissertations, Master's Theses and Master's Reports, Michigan Technological University, 2009.http://digitalcommons.mtu.edu/etds/195. 
[6] Philip W. Madson, Charles D. Tereck, 2004, "Lignocellulosic Feedstocks for Ethanol Production: The Ultimate Renewable Energy Source", AIChE Annual Meeting Austin, Texas, PP. 1-16.

[7] Sunil J. Kulkarni, Nilesh L. Shinde, Ajaygiri K. Goswami, 2015, "A Review on ethanol production from agricultural waste raw material", International Journal on Scientific Reseach in Science, Engineering and Technology, 1(4), PP.231-233.

[8] Tanmay Uttam Gound, Veena Ramachandran, Sunil Kulkarni, 2014, "Various Methods To Reduce $\mathrm{SO}_{2}$ Emission- A Review", International Journal Of Ethics In Engineering \& Management Education, 1(1), PP.1-6.

[9] Veena Ramachandran, Tanmay Uttam Gound, Sunil Kulkarni, 2014, "Biofiltration for Waste Gas Removal- A Review", International Journal of Ethics in Engineering and Management Education, 1(2), PP.8-13.

[10] Sunil J. Kulkarni, Nilesh L. Shinde, 2014, "A Review on Hydrogen Sulphide Removal from Waste Gases", International Journal of Advanced Research in Science, Engineering and Technology, 1(4), PP.187-189.

[11] Sunil Jayant Kulkarni, Ajaygiri Kamalgiri Goswami and Nilesh Shinde, 2015, "Treatment and Recovery for Flue Gases: a Review", International Journal of Research, 2(6), PP.515-519.

[12] Sunil Jayant Kulkarni, 2015, "Advancements, Research and Challenges in Reactive Adsorption: A Review", International Journal of Research, 2(1), PP.477-480.

[13] SunilJ. Kulkarni, Jayant Prabhakarrao Kaware, 2015, "Phenol removal from effluent by rice husk carbon: batch and column studies", International Journal of Environmental Engineering, 7(2), PP. $131-142$.

[14] C. Quintelas, E. Sousa, F. Silva, S. Neto, T. Tavares, 2006, "Competitive Biosorption of OrthoCresol, Phenol, Chlorophenol and Chromium (Vi) from Aqueous Solution By a Bacterial Biofilm Supported on Granular Activated Carbon”, Process Biochemistry, 41, PP.2087-2091.

[15] Jain Jyoti, Dubey Alka and Singh Jitendra Kumar, 2013, “Application Of Membrane-Bio-Reactor In Waste-Water Treatment: A Review", International Journal of Chemistry and Chemical Engineering, 3(2), PP.115-122.

[16] Mane Ashish Vilas, 2015, "A Critical Overview of Legal Profile on Solid Waste Management in India", Int. J. Res. Chem. Environ., 5(1), PP.1-16..

[17] Takele Tadesse, 2004,"Solid Waste management", University of Gondar In collaboration with the Ethiopia Public Health Training Initiative, The Carter Center, the Ethiopia Ministry of Health, and the Ethiopia Ministry of Education, 1, PP. 1-120.

[18] John Sutherland Earle, 2003, "Rotary Kiln Incineration Of Hazardous Wastes: Pilot-Scale Studies At Louisiana State University", A Dissertation Submitted to the Graduate Faculty of the Louisiana State University and Agricultural and Mechanical College in partial fulfillment of the requirements for the degree of Doctor of Philosophy, Louisiana State University, 1, PP.1-176.

[19] Y. El Naggar, E. A. Saad, A. T. Kandil and H. O. Elmoher, 2010, "Petroleum cuts as solvent extractor for oil recovery from petroleum sludge", Journal of Petroleum Technology and Alternative Fuels, 1(1), PP. 10-19.

[20] Ione L. Taylor, 2004, "Methods of Exploration and Production of Petroleum Resources", Geology, 5, PP.1-7.

[21] Voichi Uehara, 1995, "Fire Safety Assessments In Petrochemical Plants", Fire Safety ScienceProceedings Of The Third International Symposium, PP. 83-96.

[22] A.A. Aliyu And S. Saidu, 2011, "Pattern Of Occupational Hazards And Provisions Of Occupational Health Services And Safety Among Workers Of Kaduna Refinery And Petrochemical Company Ltd (KRPC), Kaduna, Nigeria", Continental J. Tropical Medicine, 5 (1), PP.1- 5, 2011.

[23] Natalie Salter, 2005, "Implementation of the Hazards and Effects Management Process (HEMP) at Shell Chemical Facilities", Presentation at the $7^{\text {th }}$ World Congress of Chemical Engineers Glasgow, Scotland July, 2005, PP. 1-10.

[24] Faith Eyayo, 2014, "Evaluation of Occupational Health Hazards among Oil Industry Workers: A Case Study of Refinery Workers", IOSR Journal of Environmental Science, Toxicology and Food Technology, 8(12), Ver. I (Dec. 2014), PP. 22-53. 
[25] Benjamin Edokpolo, Qiming Jimmy Yu and Des Connell, 2015, "Health Risk Assessment for Exposure to Benzene in Petroleum Refinery Environments", Int. J. Environ. Res. Public Health, PP. 595-610.

[26] Tobias I Ndubuisi Ezejiofor, 2014, "Risk Assessment: Re-appraisals for Potential Hazards in the Operational Environment and Facilities of Petroleum Refining and Distribution Industry in Nigeria - Research and Review", Occupational Medicine \& Health Affairs, 2(4), PP.1-19.

[27] Badrul Islam, 2015, "Petroleum Sludge, Its Treatment And Disposal : A Review", Int. J. Chem. Sci., 13(4), PP. 1584-1602.

[28] A.A. Khan, 1999, "Risk Assessment in Petrochemical Industry", First International Seminar SAFE 99 on Safety and Fire Engineering, Kochin, India, Nonember,24-26, 1999, PP.45-48.

[29] Roxana Z. Witter, Liliana Tenney, Suzanne Clark, and Lee S. Newman, 2014, "Occupational Exposures in the Oil and Gas Extraction Industry: State of the Science and Research Recommendations", 2014 Wiley Periodicals, Inc., PP.1-10.

[30] Robert Thomas Bachmann, Anbu Clemensis Johnson, Robert G.J. Edyvean, 2014, "Biotechnology in the petroleum industry: An overview", International Biodeterioration and Biodegradation, 86, PP.225-237.

\section{AUTHOR's BIOGRAPHY}

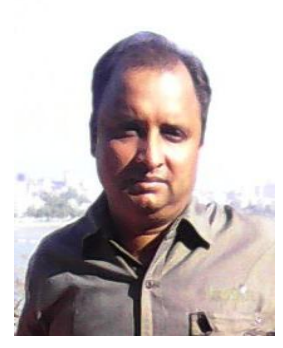

Mr. Sunil J. Kulkarni, has completed his Masters in Chemical Engineering from Tatyasaheb Kore Institute of Engineering and Technology, Warananagar in 2006. $\mathrm{He}$ is currently pursuing his $\mathrm{PhD}$ in chemical engineering. He is working as Assistant Professor in Chemical Engineering Department of Datta Meghe College of Engineering, Airoli, Navi Mumbai, India. The author has 16 years of experience in teaching and research. He has published 113 international review and research papers and presented 15 research papers in international conferences. His area of research includes adsorption, environmental engineering and catalysis. $\mathrm{He}$ is editorial board member of more than 25 international journals and reviewed many international papers. 